\title{
H19 Gene
}

National Cancer Institute

\section{Source}

National Cancer Institute. H19 Gene. NCI Thesaurus. Code C20058.

This gene plays a role in genomic imprinting and may be involved in the negative regulation of cell growth. 